\title{
Specific Obesity-related Adipokines
}

Giovanna Zuzarte Candido, Isabelle Leticia Zaboroski Silva, Laysa Toschi Martins, Letícia Koczicki, Karen Sumire Kubo and Henrique Ravanhol Frigeri*

Health and Biosciences School, Pontifical Catholic University of Parana, Brazil

Keywords: Adipokines; Obesity; Leptin; Adiponectin; Tumor necrosis factor-alfa; Inflammation

\section{Dear Editor,}

Obesity is defined as abnormal or excessive fat accumulation that presents a risk to health [1]. The most important associated elements of this tissue are the fatty acids, however the adipocytes might secrete immunological components, such as prostaglandins. In the last 12 years, the endocrine role of the adipose tissue by its ability to secrete molecules with biological effects has also been discovered. Furthermore, this tissue was considered, by many researchers, as a dynamic organ involved in a variety of metabolic and physiological processes [2]. Apart from that, adipocytes might secrete a variety of bioactive peptides called adipokines. An alteration on adipokines secretion can be caused by excessive growth of adipose tissue, which can leads to adipocyte hypertrophy [3].

The investigation of pro-inflammatory cytokines, such as interleukin-6 (IL-6), tumor necrosis factor-alfa (TNF- $\alpha$ ), leptin (LEP), and the anti-inflammatory molecules, as well as adiponectin, has shown association of chronic inflammation with obesity. This connection might be represented by the increased levels of cytokines in blood and other acute proteins associated with inflammation in obese subjects. Cytokines that are secreted by cells of the white adipose tissue are mediator and regulator hormones of inflammatory responses. By convention cytokines produced by adipocytes are called adipokines and the most studied are the leptin and adiponectin $[2,4]$.

\section{Leptin and adiponectin}

In 1994, leptin was discovered as the product of the "obese gene" ( ob, actually in humans $L E P$ ), after called leptus (thin). Leptin is a 16 $\mathrm{kDa}$ polypeptide hormone constituted by 167 amino acid residues [5]. Leptin acts on the central nervous system and regulates the mechanism involved in food intake, energy expenditure and consequently, body weight [6]. Furthermore, leptin has effects on: i) naïve cells to T-lymphocytes differentiation process; ii) memory T-cells; and iii) increased production of proinflammatory lymphokines [2]. While leptin modulates immune response, in other tissues, this cytokine has important metabolic functions. In pancreas, leptin might regulate insulin secretion. In liver and in muscle, it is involved, respectively, on glucose production and uptake [7].

The adiponectin is the most abundant factor produced by adipocytes. This molecule increases insulin sensitivity and inhibits vascular inflammation. The adiponectin biological effects do not depend only of its current levels, but also of the tissue specificity and the interaction with its receptors, called ADP-R1 and ADP-R2 $[8,9]$. Adiponectin also increases insulin sensitivity and protects from cardiovascular events [10]. Blood adiponectin circulates bound to Low Molecular Weight (LMW) and Higher Molecular Weight (HMW). Neumeier et al. (2006) reported that the HMW can exert proinflammatory effects through the induction of IL-6 synthesis. However, LMW attenuates IL- 6 synthesis and enhances the IL -1RA synthesis, favoring anti-inflammatory action. The Figure 1 shows examples of the immune effects of the leptin and adiponectin.

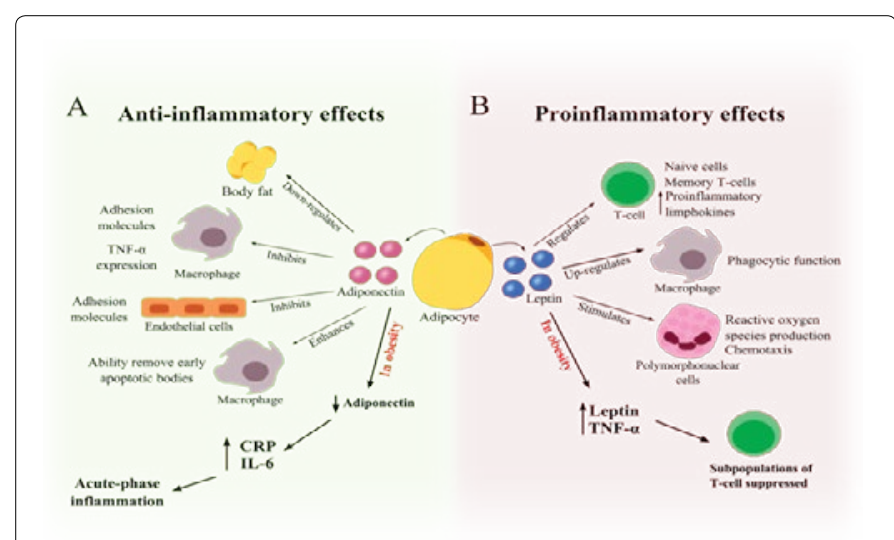

Figure 1: Adiponectin, leptin and their effects in immune system and obesity. A. Adiponectin has an anti-inflammatory effect, promoting the reduction of inflammatory response as shown by several mechanisms. In obesity, adiponectin levels are low, promoting the acute phase of inflammation. B Leptin has a proinflammatory effect, promoting the increase of inflammatory response. In obesity, leptin levels are high, suppressing or increasing some kind of T-cells populations, increasing the inflammatory response in adipose tissue.

\section{TNF- $\alpha$ action on adipose tissue}

The TNF- $\alpha$ might be originated from the adipocyte, however a considerable amount of this factor can be produced and secreted by macrophages whose infiltration is enhanced by leptin. When macrophages are in the adipose tissue, these cells participate in the obesity development mechanism $[4,11,12]$. However, TNF- $\alpha$ mRNA from adipocytes was positively correlated with increased body mass index (BMI), fat body percentage and hyperinsulinemia [13].

TNF- $\alpha$ and adiponectin are inhibited each other. The C-Reactive Protein (CRP) production is negatively controlled by adiponectin and this molecule expression is suppressed by IL-6. The adiponectin inhibits monocytes induction, endothelial and macrophage adhesion molecules expression and macrophage activation process. In addition, adiponectin reduces macrophages TNF- $a$ expression, smooth muscle cells proliferation and vascular cell adhesion molecule-1 (VCAM1) expression [14].

*Corresponding author: Henrique Ravanhol Frigeri, Health and Biosciences School, Pontifical Catholic University of Parana Curitiba, Parana, Brazil Rua imaculada Conceição, 115580215-901 Curitiba, PR, Brazil, Tel: +55-41-32711515; E-mail: henrique.frigeri@gmail.com

Received November 02, 2015; Accepted November 14, 2015; Published November 21, 2015

Citation: Candido GZ, Silva ILZ, Martins LT, Koczicki L, Kubo KS, et al. (2015) Specific Obesity-related Adipokines. Immunochem Immunopathol 1: 108. doi: 10.4172/2469-9756.1000108

Copyright: (c) 2015 Candido GZ, et al. This is an open-access article distributed under the terms of the Creative Commons Attribution License, which permits unrestricted use, distribution, and reproduction in any medium, provided the original author and source are credited. 
Citation: Candido GZ, Silva ILZ, Martins LT, Koczicki L, Kubo KS, et al. (2015) Specific Obesity-related Adipokines. Immunochem Immunopathol 1: 108. doi: 10.4172/2469-9756.1000108

Page 2 of 2

While a lot of studies were conducted to clear even more the relationship of immune processes and obesity, the complete mechanism is still unclear and more experimental studies are necessary to better understand the influence of the major immune factors in adipose tissue and obesity.

\section{Acknowledgements}

We are thankful to the Health and Biosciences School of the Pontifical Catholic University of Parana, CNPq and the Araucaria Foundation for the support.

\section{Conflict of Interest}

The authors declare no potential conflicts of interest relevant to this article.

\section{References}

1. World Health Organization (2015) Obesity and overweight.

2. Prado W L, Lofrano MC, Oyama LM, Dâmaso AR (2009) Obesidade Adipocinas Inflamatórias: Implicações Práticas para a Prescrição de Exercício. Rev Bras Med Esporte 15: 378-383.

3. Khodabandeloo H, Gorgani-Firuzjaee S, Panahi S, Meshkani R (2015) Molecular and cellular mechanisms linking inflammation to insulin resistance and beta-cell dysfunction. Transl Res.

4. Weisberg SP, McCann D, Desai M, Rosenbaum M, Leibel RL, et al. (2003) Obesity is associated with macrophage accumulation in adipose tissue. Journal of Clinical Investigation 112: 1796-1808

5. Ghalandari H, Hosseini-Esfahani F, Mirmiran P (2015) The Association of Polymorphisms in Leptin/Leptin Receptor Genes and Ghrelin/Ghrelin Receptor Genes With Overweight/Obesity and the Related Metabolic Disturbances: A Review. Int J Endocrinol Metab 13: e19073.
6. Hart RA, Dobos RC, Agnew LL, Tellam RL, McFarlane JR (2015) Pharmacokinetics of leptin in female mice. Physiol Res.

7. La Cava A, Matarese G (2004) The weight of leptin in immunity. Nat Rev Immunol 4: 371-379.

8. Silveira MR, Frollini AB, Verlengia R, Cavaglieri CR (2009) Correlation between obesity, adipokines and the immune system. Rev Bras Cineantropom Desempenho Hum 11: 466-472.

9. Winzer C, Wagner O, Festa A, Schneider B, Roden M, et al. (2004) Plasma adiponectin, insulin sensitivity, and subclinical inflammation in women with prior gestational diabetes mellitus. Diabetes Care 27: 1721-1727.

10. Ronti T, Lupattelli G, Mannarino E (2006) The endocrine function of adipose tissue: an update. Clin Endocrinol (Oxf) 64: 355-365.

11. Neumeier M, Weigert J, Schaffler A, Wehrwein G, Muller-Ladner U, et al. (2006) Different effects of adiponectin isoforms in human monocytic cells. $J$ Leukoc Biol 79: 803-808.

12. Bullo M, Casas-Agustench $P$, Amigo-Correig P, Aranceta J, Salas-Salvado J (2007) Inflammation, obesity and comorbidities: the role of diet. Public Health Nutr 10: 1164-1172.

13. Jellema A, Plat J, Mensink RP (2004) Weight reduction, but not a moderate intake of fish oil, lowers concentrations of inflammatory markers and PAI1 antigen in obese men during the fasting and postprandial state. Eur $\mathrm{J}$ Clin Invest 34: 766-773.

14. Ouchi N, Kihara S, Funahashi T, Matsuzawa Y, Walsh K (2003) Obesity adiponectin and vascular inflammatory disease. Curr Opin Lipidol 14: 561-566. 